DOI: 10.20472/IAC.2018.001.002

\title{
PONKRIT CHIDCHOB
}

Suan Sunandha Rajabhat University, Thailand

CHUENAAROM CHANTIMACHAIAMORN

Suan Sunandha Rajabhat University, Thailand

SITTICHAI THAMMASANE

Suan Sunandha Rajabhat University, Thailand

\section{THE USE OF LINE APPLICATION AS A COMMUNICATION MEDIA BY THE STAFF MEMBERS OF THE GRADUATE SCHOOL, SUAN SUNANDHA RAJABHAT UNIVERSITY, THAILAND}

\begin{abstract}
:
This research primarily aims to study the use of Line application to communication among the staff members of the Graduate School of Suan Sunandha Rajabhat University and to examine their satisfaction upon the use of such application. This research was a quantitative research study. The research was carried out between September 2017 and July 2018. The research sample was 40 staff members of the Graduate School. Data were gathered by the use of a questionnaire and analyzed with descriptive statistics including percentage, mean, and standard deviation. The research findings showed that in terms of the main topics of communication, the topics related to the organization was discussed the most via Line application. According to the sample, their opinion upon use of Line application to discuss the information related to the organization was rated at a high level. Special topics of discussion included the development of study program, information on students' registration, research and academic service activities. These discussions were to ensure that the team members would understand the details of these aspects correctly ( $X=3.81$ ). In terms of general information, it was found that the sample rated the use of Line application to discuss general information at the highest level. The topics of discussion included searching for various kinds of knowledge such as food, tourism, and health $(X=3.91)$. Moreover, the overall satisfaction upon the use of Line application (i.e. its response, the purpose of using, convenience, speed, accuracy, and communication) was at high level $(X=3.86)$. Lastly, the study revealed that staff members with different gender, age, marital status, education level, work position, the faculty they work for differed in their satisfaction on the use of social media with a .01 and .05 level of statistical significance.
\end{abstract}

\section{Keywords:}

Use of Line Application, Communication, Staff Members

JEL Classification: Y80 


\section{Background and Significance of the Research}

Communication via social media is a two-way communication which involves two groups of people: message senders and message receivers. These people can communicate simultaneously without having a limitation of place. Through social media, people can interact with others fast and easily wherever they are.

The term 'social media' or 'social network' can be defined as media that allow people to communicate via online network. Social refers to 'a society' or in this case means 'online society' whereas media are tools or intermediaries used to exchange or transfer the message between senders and receivers. We can say that social network is part of social media. All the media used in online society can be considered as social media. If we would like to emphasize only 'networks' of online society, the term 'social network' should be used

Social media are now used for various purposes. Some people use them for the purpose of entertaining, some use to communicate with others, some use to express their opinion, and some use for sharing their experiences. Social media are also used by many organizations for the purpose of promotion, informing news, and announcing activities.

Nowadays, communicating via social media is very modern and advanced. Information can be sent from senders to receivers in various forms such as in a form of pictures, video clips, text, or voice At present, many schools have adopted computer and information technology. This is a great way to learn and learn from the lessons learned in eLearning. This is a flexible learning style based on the skills and abilities of the learner.( Krairop Charoensopa, 2010)

This way of communication is the most widely used in today's society. There are many types of social media that have been developed. Some are called 'published media' which are used to distribute or give information on certain topics such as Wikipedia Blogger. Some are media that are used to share information to other such as YouTube, Flickr, and SlideShare etc. Some social media are used to provide a platform for discussion between or among people such as MSN, Skype, Google Talk etc.

Social media and social network increasingly play an important role in today's society. They can connect people from every corner of the world using established network. They can also connect us to former friends who we have not met or contacted for a long time. Social media and social network are social platforms which have no limitation both in terms of time and scope of network. It seems that social media and social network minimize the world and allows people to be connected to each other more conveniently. 
Although social media and social network can be very beneficial in terms of speed and places, communication through them can be a way that allows unknown people to gain access to us at anywhere and anytime and we may not be aware of this.

Line application is one form of social media which is widely used nowadays. It is used for various purposes. Many organizations use Line application as a main way of communication between their staff members.

Upon realizing the important role of social media and social network, the researcher was interested to study behaviour of people in using social media because nowadays, people can use them both for their own benefits and for the benefits of the whole organization. The researcher believed that using social media and social network as a way of communication can lessen a gap between people.

\section{Research Objectives}

This research primarily aims to:

1. Study the use of Line application to communication among the staff members of the Graduate School of Suan Sunandha Rajabhat University; and 2. Examine their satisfaction upon the use of such application.

\section{Scope of the Research}

\section{Scope of content}

This study aimed to study on three main aspects:

1) Behavior in using Line application

2) Issues of discussion/communication via Line application

3) Satisfaction upon the use of Line application

\section{Scope on population}

The population of this research were the staff members of the Graduate School of Suan Sunandha Rajabhat University, Thailand.

Scope on period of study

The research was carried out between September 2017 and July 2018. 


\section{Research Methodology}

This research utilized a quantitative research methodology.

Population and sample

The population of this research were staff members of the Graduate School. At the time of conducting this research, there were 40 staff members. As the number of population was known and small. All of the them were selected as the respondents of this study.

\section{Data collection instrument}

In this research, the researcher used a self-administered questionnaire as a main data collection tool. It was developed by the researcher. There were four main parts in this questionnaire containing both close-ended and open-ended questions, namely:

Part I contained questions on general demographic background of the respondents including age, gender, marital status, educational level and job position. These were close-ended questions.

Part II contained questions on behavior in using social media. They were both closeended and open-ended questions. This part aimed to examine the following aspects:

1. The use of Line application

\subsection{How to use}

1.2 Frequency of using and time spent for each time of use

2. Issues of communication or discussion

2.1 Issues related to the organization

2.2 General issues

Part III contains questions on satisfaction on the use of social media

Part IV was a part where the respondents could express their idea or suggestions on the use of social media freely. It was an open-ended question.

Data analysis

The data were analyzed with descriptive statistics including percentage, mean, and standard deviation. 


\section{Research Findings}

Based on data analysis, four main aspects of the behavior of Graduate School's staff members in using Line application as a way to communicate.

\section{1) The behavior in using Line application}

It was found that the staff members used Line application both on their personal mobile phones and on personal computers. In terms of frequency in using, they used it every day and each time took less than 30 minutes.

\section{2) Issues of communication or discussion}

In terms of the main topics of communication, the topics related to the organization was discussed the most via Line application. According to the sample, their opinion upon use of Line application to discuss the information related to the organization was rated at a high level. Special topics of discussion included the development of study program, information on students' registration, research and academic service activities. These discussions were to ensure that the team members would understand the details of these aspects correctly $(\bar{X}=3.81)$. In terms of general information, it was found that the sample rated the use of Line application to discuss general information at the highest level. The topics of discussion included searching for various kinds of knowledge such as food, tourism, and health $(\bar{X}=3.91)$.

\section{Overall satisfaction on the use of Line application}

The study revealed that the overall satisfaction of the staff members upon the use of Line application (i.e. its response, the purpose of using, convenience, speed, accuracy, and communication) was at high level ( $\bar{X}=3.86)$.

Lastly, the study revealed that staff members with different gender, age, marital status, education level, work position, the faculty they work for differed in their satisfaction on the use of social media with a .01 and .05 level of statistical significance.

4. Other opinion and suggestions on the use of Line Application as a means of communication

Most of the staff members thought that the organization should provide them with basic knowledge for using social media and encourage them to be aware of the way to use them appropriately. 


\section{References}

Ritthongpitak, O. (1996). The Use of World Wide Web on Internet Among University Students. Unpublished Master Dissertation. Bangkok: Chulalongkorn University.

Chaikhan, S. (2011). Behavior of Students Using Social in Secondary School (M.1-M.3) Janokrong School Phitsanulok Province. Unpublished Independent Study. Phitsanulok: Naresuan University.

Charoensopa. K. (2010). The Development of E-learning in Relief printing on “ Flexographic print" of undergraduate students, Department of Printing technology, Suan Sunandha Rajabhat University 